\title{
Case Report on Obsessive Compulsive Disorder
}

\author{
${ }^{*}$ Ms.Deepika $V,{ }^{* *} M$ s.Prabavathy $S$ \& ***Ms.Jayasri J
}

\begin{abstract}
:
Obsessive-compulsive disorder (OCD) is a mental disorder where people feel the need to check things repeatedly, perform certain routines repeatedly (called "rituals"), or have certain thoughts repeatedly (called "obsessions"). Obsessive compulsive disorder (OCD) is a debilitating neuropsychiatric disorder with a lifetime prevalence of 2 to 3 percent and is estimated to be the 10th leading cause of disability in the world. People are unable to control either the thoughts or the activities for more than a short period of time. Obsessive compulsive disorder (OCD) was once thought to be extremely rare, but recent epidemiological studies have shown it to be the fourth most common psychiatric disorder (after substance abuse, specific phobias, and major depression). OCD is often a chronic disorder that produces significant morbidity when not properly diagnosed and treated. The mainstay of treatment includes cognitive behavioral therapy and medication management.
\end{abstract}

Keyword: Obsessive compulsive disorder, obsessions, rituals, cognitive behavior therapy, medical management.

\section{INTRODUCTION}

\section{Case report}

A 28 year female got admitted with the complaints Thoughts to bite male and female private part, Thoughts like brushing using a broomsticks, Impulse to throttle her mother on slit or throat using a saw, Feels like there is a blood or feces on her plate of food, Irritability and anger burst, Crying spells for 8 months, Thoughts to bite soap, Thoughts to bite her hand, Tried to strangulate herself for with her dhupatta for 2 days. Her vital signs are BP 120/80mm $\mathrm{Hg}$, pulse 98 beats/ min, respiration 20 breathes/ min and temperature $98.8 \mathrm{deg} \mathrm{F}$.
Patient had a previous history of same complaints and she had a poor drug compliance, so that she developed her symptoms. Patient had improved her condition after her treatment schedule.

\section{Definition}

Obsessive compulsive disorder is an anxiety disorder in which people have unwanted and repeated thoughts, feelings, ideas, sensations (obsessions), or behaviors that make them driven to do something (compulsions)and engage in behaviours or mental acts in response to these thoughts or obsessions. 


\begin{tabular}{|c|c|c|}
\hline S. No & Book picture & Clinical picture \\
\hline I. & \multicolumn{2}{|c|}{ Etiological factors } \\
\hline 1. & $\begin{array}{l}\text { GENETIC FACTORS } \\
\text { 35\% of the first degree relatives of } \\
\text { obsessive-compulsive disorder. }\end{array}$ & $\begin{array}{l}\text { Family history of psychosis and post } \\
\text { partum depression. }\end{array}$ \\
\hline 2. & $\begin{array}{l}\text { BIOCHEMICAL INFLUENCES } \\
\text { Alteration in Nor epinephrine and } \\
\text { serotonin causes OCD. }\end{array}$ & - \\
\hline 3. & $\begin{array}{l}\text { PSYCHOANALYTIC THEORY } \\
\text { Use of defense mechanisms like } \\
\text { isolation, undoing, displacement and } \\
\text { reaction formation, may lead to OCD. }\end{array}$ & $\begin{array}{l}\text { - She is an introvert person, she } \\
\text { isolates herself, she didn't } \\
\text { maintain a good relationship } \\
\text { with her family members and } \\
\text { friends, she had an undoing habit } \\
\text { of biting her hand instead of } \\
\text { killing her mother. } \\
\text { - Her grandfather death. }\end{array}$ \\
\hline 4. & $\begin{array}{l}\text { BEHAVIOR THEORY } \\
\text { Obsessions as a conditioned stimulus } \\
\text { to anxiety. }\end{array}$ & $\begin{array}{l}\text { Exam failure, fear of going to school, } \\
\text { low esteem. }\end{array}$ \\
\hline 5. & $\begin{array}{l}\text { STRESS THEORY } \\
\text { Stressful life events. }\end{array}$ & Death of her grandfather. \\
\hline II. & \multicolumn{2}{|c|}{$\begin{array}{l}\text { PSYCHOPATHOLOGY } \\
\text { Obsessive-compulsive disorder (OCD) is characterized by the presence of } \\
\text { either obsessions or compulsions, but commonly both.... Obsessions or } \\
\text { compulsions can occur in the context of other disorders such as } \\
\text { schizophrenia, depression and Tourette's syndrome }\end{array}$} \\
\hline III. & \multicolumn{2}{|c|}{ CLINICAL MANIFESTATIONS } \\
\hline 1. & $\begin{array}{l}\text { OBSESSIONAL THOUGHTS: } \\
\text { Words, ideas and beliefs that intrude } \\
\text { forcibly into patients mind. }\end{array}$ & $\begin{array}{l}\text { She had obsessive thoughts to } \\
\text { strangulate her mother, biting } \\
\text { herself, biting soaps. }\end{array}$ \\
\hline 2. & $\begin{array}{l}\text { OBSESSIONAL IMAGES: } \\
\text { Vividly imagined scenes, often a } \\
\text { violent, sexual practices }\end{array}$ & No obsessive images \\
\hline 3. & $\begin{array}{l}\text { OBSESSIONAL RUMINATIONS: } \\
\text { Compulsively focused attention on } \\
\text { the symptoms }\end{array}$ & $\begin{array}{l}\text { She had focused attention towards } \\
\text { killing her mother and spitting on } \\
\text { others. }\end{array}$ \\
\hline
\end{tabular}




\begin{tabular}{|c|c|c|}
\hline 4. & $\begin{array}{l}\text { OBSESSIONAL DOUBTS: } \\
\text { Forgetting to turn off the stove or not } \\
\text { locking a door. }\end{array}$ & No obsessive doubts \\
\hline 5. & $\begin{array}{l}\text { OBSESSIVE IMPULSES: } \\
\text { Violent or embarrassing kind, such as } \\
\text { injuring a child, shouting in church }\end{array}$ & $\begin{array}{l}\text { Impulse to throttle her mother or cut } \\
\text { the throat by using a saw. }\end{array}$ \\
\hline 6. & $\begin{array}{l}\text { OBSESSIVE RITUALS: } \\
\text { Counting repeatedly in such a way or } \\
\text { repeating a certain form of words or } \\
\text { senseless repeated behavior }\end{array}$ & No obsessive rituals \\
\hline 7. & $\begin{array}{l}\text { OBSESSIVE SLOWNESS: } \\
\text { - } \quad \text { Recognition that the thoughts are } \\
\text { produced in his or her own mind } \\
\text { - Lack of concentration and task } \\
\text { completion } \\
\text { - Impaired social or work } \\
\quad \text { functioning }\end{array}$ & Obsessive slowness present \\
\hline IV & \multicolumn{2}{|c|}{ DIAGNOSTIC EVALUATION } \\
\hline 1. & History collection & $\begin{array}{l}\text { History noted such as she had non- } \\
\text { compliance of drugs, family history } \\
\text { of psychiatric illness, school dropout, } \\
\text { low self esteem, poor IPR with friends } \\
\text { and teachers. }\end{array}$ \\
\hline 2. & Mental status examination & $\begin{array}{l}\text { Findings noted such as crying spells, } \\
\text { decreased psychomotor activity, } \\
\text { obsessive thoughts and obsessive } \\
\text { impulses. Mood is appropriate to } \\
\text { affect. Affect is unpleasurable. } 1^{\text {st }} \\
\text { degree True insight is present. }\end{array}$ \\
\hline 3. & Based on ICD 10 criteria & F42 Obsessive Compulsive Disorders \\
\hline 4. & $\begin{array}{l}\text { MRI and CT brain shows enlarged } \\
\text { basal ganglia in some patients for } \\
\text { OCD and changes in the } \\
\text { ventricular volume for depression }\end{array}$ & - \\
\hline 5. & $\begin{array}{l}\text { Positron Emission Tomography } \\
\text { shows increased glucose } \\
\text { metabolism in part of the basal } \\
\text { ganglia }\end{array}$ & - \\
\hline 6. & Yale-Brown Obsessive Compulsive & Scoring was 24, shows moderate \\
\hline
\end{tabular}




\begin{tabular}{|c|c|c|}
\hline & $\begin{array}{l}\text { Scale } \\
\text { (Y-BOCS) } \\
\text { Scoring and interpretation } \\
\text { Score ranges from } 0-40 \\
0-20 \text { sub case of } O C D \\
21-30 \text { moderate } O C D \\
31-40 \text { severe } O C D \\
\end{array}$ & $O C D$ \\
\hline$V$ & \multicolumn{2}{|l|}{ MANAGEMENT } \\
\hline 1. & $\begin{array}{l}\text { Antidepressants } \\
\text { Fluvoxamine } 20 \mathrm{mg} \text { in a } 3 \text { divided } \\
\text { doses } \\
\text { Sertraline } 50-200 \mathrm{mg}\end{array}$ & T. Fluvoxetine $20 \mathrm{mg}$ 3-0-0 \\
\hline 2. & $\begin{array}{l}\text { Anxiolytics } \\
\text { Benzodiazepines- Valium and } \\
\text { Diazepam }\end{array}$ & - \\
\hline 3. & $\begin{array}{l}\text { Mood stabilizers } \\
\text { T.Lamotrigine } 75 \mathrm{mg} / \text { day } \\
\text { T.Divalproex Sodium } 60 \mathrm{mg} / \mathrm{kg} \text { daily } \\
\text { T. Carbamazipine } 600 \mathrm{mg} / \text { day in a } \\
\text { divided doses }\end{array}$ & $\begin{array}{l}\text { T. Lamotrigine } 25 \mathrm{mg} 0-0-3 \\
\text { T. Oxcarbazipine } 150 \mathrm{mg} \mathrm{0-0-1}\end{array}$ \\
\hline 4. & $\begin{array}{l}\text { Antipsychotics } \\
\text { T. Aripiprazole } 10 \mathrm{mg} \\
\text { T. Clonazepam } 1 \mathrm{mg}\end{array}$ & $\begin{array}{l}\text { T. Aripiprazole } 10 \mathrm{mg} \text { 3-0-0 } \\
\text { T. Clonazepam } 1 \mathrm{mg} \text { 1-0-1 }\end{array}$ \\
\hline$V I$ & \multicolumn{2}{|l|}{ THERAPIES } \\
\hline 1. & Electro Convulsive Therapy & 6 sessions of ECT were given \\
\hline 2. & Thought Stopping techniques & $\begin{array}{l}\text { Thought stopping technique has been } \\
\text { taught to the patient. She used to } \\
\text { practice daily. }\end{array}$ \\
\hline 3. & Relaxation techniques & $\begin{array}{l}\text { Deep breathing techniques have been } \\
\text { taught. }\end{array}$ \\
\hline 4. & Supportive therapies & $\begin{array}{l}\text { Supportive therapy given such as } \\
\text { Yoga and Music therapy. }\end{array}$ \\
\hline 5. & Counseling & $\begin{array}{l}\text { Individual and family counseling } \\
\text { given }\end{array}$ \\
\hline VII & \multicolumn{2}{|c|}{$\begin{array}{l}\text { DIFFERENTIAL DIAGNOSIS: } \\
\text { OCD is often confused with the separate condition obsessive- } \\
\text { compulsive personality disorder (OCPD). OCD is egodystonic, meaning that } \\
\text { the disorder is incompatible with the sufferer's self-concept. Because ego }\end{array}$} \\
\hline
\end{tabular}




\begin{tabular}{|c|c|}
\hline & $\begin{array}{l}\text { dystonic disorders go against a person's self-concept, they tend to cause } \\
\text { much distress. OCPD, on the other hand, Is egosyntonic- marked by the } \\
\text { person's acceptance that the } \\
\text { characteristics and behaviours displayed as a result are compatible with } \\
\text { their self-image, or are otherwise appropriate, correct or reasonable. } \\
\text { As a result, people with OCD are often aware that their behavior is } \\
\text { not rational, are unhappy about their obsessions but nevertheless feel } \\
\text { compelled by them. By contrast people with OCPD are not aware of } \\
\text { anything abnormal; they will readily explain why their actions are rational, } \\
\text { it is usually impossible to convince them otherwise, and they tend to derive } \\
\text { pleasure from their obsessions or compulsions. }\end{array}$ \\
\hline VIII & $\begin{array}{l}\text { PROGNOSIS } \\
\text { OCD patients tend to seek treatment from } 3 \text { to } 4 \text { doctors and spend } 9 \text { years } \\
\text { in treatment before a correct diagnosis is made. The average amount of } \\
\text { time that lapses between onset of symptoms and appropriate treatment is } \\
17 \text { years. While controlled trials with serotonin reuptake inhibitors have } \\
\text { demonstrated a selective efficacy in OCD, up to } 40 \% \text { to } 60 \% \text { of patients do } \\
\text { not have a satisfactory outcome. These patients have significant disability } \\
\text { and morbidity. The natural course is lifelong, and patients generally } \\
\text { require lifelong treatment. } \\
\text { Features associated with treatment resistance include: higher } \\
\text { frequency of compulsions; early age of onset; previous hospitalizations for } \\
\text { OCD; and chronic course (the longer the disorder goes untreated, the more } \\
\text { likely patients are to exhibit resistant symptoms). Male gender is } \\
\text { associated with an earlier onset and chronic course, and often predicts } \\
\text { poorer response to treatment. Concomitant schizotypal personality } \\
\text { disorder is considered a predictor of worse response and may warrant } \\
\text { early referral to specialist to tailor therapy. The presence of a concurrent } \\
\text { tic disorder may be associated with more severe OCD symptoms and } \\
\text { greater likelihood of treatment resistance. }\end{array}$ \\
\hline
\end{tabular}

\section{References:}

1. Davis, Kenneth L, Neuropsychopharmacology:5th edition, 2002, Lippincott Williams \& Wilkins. Philadelphia pp. 1609-1610

2. Hyman, Bruce and Troy DeFrene. Coping with OCD. $4^{\text {th }}$ edition, 2008. New Harbinger Publications pp. 1243-1250

3. Diagnostic and statistical manual of mental disorders: DSM-5 $5^{\text {th }}$ edition. 2013, Washington: American Psychiatric Publishing.pp. 237-242. 
4. Rapoport, J. E. Obsessive-compulsive Disorder : Children \& Adolescents.10 th edition,1989 Washington: American Psychiatric Press.pp.243-255

5. Angelakis, I; Gooding, P; Tarrier, N; Panagioti, M, "Clinical Psychology, Suicidality in obsessive compulsive disorder (OCD):" 12 th edition: March 2015,New Harbinger Publications, 334-352.

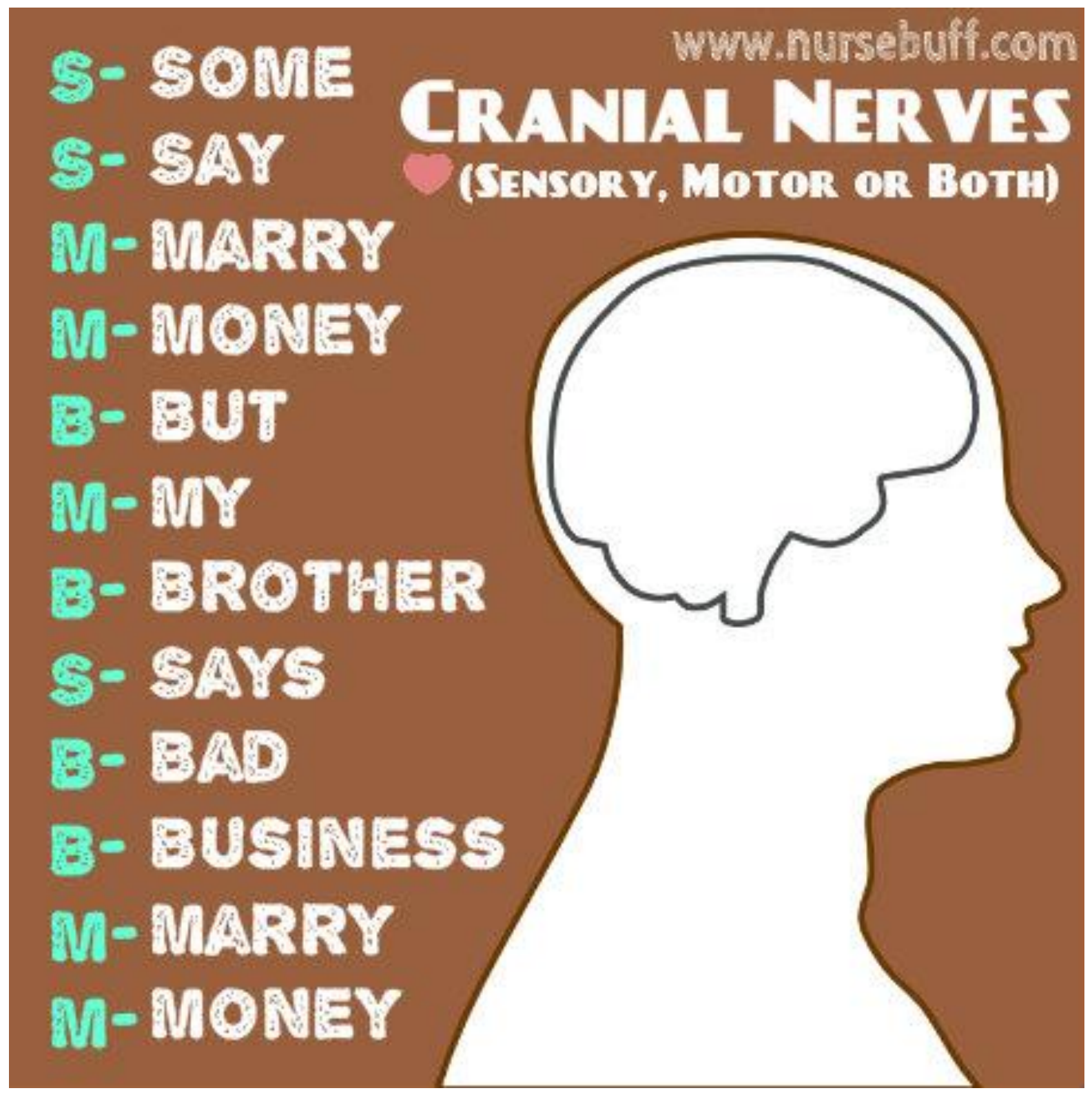

